PSICOLOGÍA

IBEROAMERICANA
Psicología Iberoamericana ISSN: 1405-0943

revista.psicologia@ibero.mx

Universidad Iberoamericana, Ciudad de México México

\title{
Violence against women in the developing world: Mexico and the migrant crisis
}

Gordon, Sarah Frances

Violence against women in the developing world: Mexico and the migrant crisis

Psicología Iberoamericana, vol. 26, no. 1, 2018

Universidad Iberoamericana, Ciudad de México, México

Available in: http://www.redalyc.org/articulo.oa?id=133959553002 


\title{
Violence against women in the developing world: Mexico and the migrant crisis
}

\author{
Sarah Frances Gordon sarah.gordon@ibero.mx \\ Universidad Iberoamericana, México
}

Violence against women is a global epidemic that affects 1 in 3 women in their lifetime and research suggests that as many as $38 \%$ of murders of women are committed by intimate partners (WHO, 2017; The World Bank, 2018). Violence against women and public security are some of the challenges facing Mexico at the moment (OHCHR, 2018). In Mexico, the statistics are grim $66.1 \%$ of girls and women aged 15 or older have experienced gender-based violence at least once in their lives and that $43.5 \%$ of women have experienced gender-based violence committed by their partners (Amnesty International, 2018). Femicide is a national problem in Mexico and at least 400 women have been brutally murdered during the last decade in Ciudad Juárez (Joseph, 2017; WHO, 2012). However, a lack of reliable reporting on violence against women makes it difficult to accurately estimate the extent of this epidemic.

Violence against women appears to be culturally ingrained in Mexico. This can be seen in Bauer, Rodriguez, Quiroga, and Flores-Ortiz's (2000) research with Mexican immigrants, which showed that women prioritise keeping their marriages intact over their own personal safety, often tolerating partner-abuse because of their belief in the sanctity of marriage and the importance of family. Furthermore, the prevalence of violence against women in Mexico can be viewed as an expression of the country's current crises of governability, internal security, drug trafficking, as well as the dominant culture of machismo in the country (Ertürk, 2006; OHCHR, 2018; Olivera, 2006). The presence of a machista culture, in which men exaggerate the violent, authoritarian, aggressive aspects of male identity, can be seen in the socially entrenched gender inequality and sexist, patriarchal structures in Mexico $(\mathrm{OHCHR}$, 2018; Olivera, 2006). The machista culture in Mexico relegates women to subordinate roles and women are expected to define themselves in relation to their husbands and domestic responsibilities, denying them an independent existence (Ertürk, 2006). This makes it difficult for them to combat abuse and access support. It also creates an environment where violence against women can flourish. These factors are further compounded by other stressors in the country such as unemployment, poverty, social polarization, and the inability of the government and legal system to effectively respond to violent crime, making Mexico 
particularly susceptible to high levels of violence against women (Ertürk, 2006; Olivera, 2006).

Indigenous women in Mexico are also likely targets of violence due to the traditional patriarchal gender hierarchies of indigenous communities, ethnic stereotyping and discrimination (Ertürk, 2006). Research indicates that authorities in indigenous communities use customary and social norms to normalize domestic violence, further entrenching the marginalization of indigenous women in Mexico (Mejía Flores, 2006).

In addition, situations of conflict and displacement, such as the current migrant crisis in Central and Latin America, may exacerbate existing violence against women in the region (WHO, 2017). Migrant women and girls typically enter Mexico to seek better opportunities or in transit to the U.S. Violence against women is a risk along the route through Mexico, with the southern border from Guatemala to Mexico being considered particularly volatile (Cuffe, 2018; Ertürk, 2006). Furthermore, the nature of migratory patterns makes migrant women and girls especially vulnerable to exploitation, violence and human trafficking (Ertürk, 2006; OHCHR, 2018). Undocumented migrant women's vulnerability in Mexico is further compounded by Mexican migration law which prohibits undocumented migrants from accessing State authorities and The General Population Act (Ley General de Población), which prohibits State authorities from processing any request from a non-citizen who has not demonstrated their legal status in Mexico (Ertürk, 2006). Whilst tensions over immigration continue to intensify in the region, foreign ministers hope that the new Comprehensive Development Plan, which promises to promote development in Central America and Mexico, will help revitalise the region and address the structural causes of the migrant crisis (ECLAC, 2018).

Addressing the problem of violence against women in Mexico requires a multi-pronged, complex approach, which also considers the social and political challenges facing the country. The most effective ways to reduce violence against women include education programmes aimed at challenging gender norms and roles that reinforce the subordination of women; and initiatives that address the social norms that reinforce the acceptability of violence in society. While the passage of laws prosecuting perpetrators of femicide and other forms of violence against women, are useful and have been implemented in Mexico, it does little to address the machista culture, which is responsible for perpetuating gender inequality and the subordination of women (Joseph, 2017). Only once the patriarchal ideological beliefs, entrenched in machista culture, are dismantled will Mexico be able to rid itself of violence against women.

The field of psychology plays a significant role in addressing the social challenges facing México, specifically violence against women and the migrant crisis. Psychologists are at the forefront of these issues and need to be aware of the driving forces behind these social problems. Therefore, as professionals, it is important that we challenge ourselves and address 
any preconceived notions we have about violence against women and the migrant crisis so that we are better able to serve our community.

\section{REFERENCES}

Amnesty International. (2018). Mexico 2017/2018 | Amnesty International. Retrieved from Amnesty International website: https://www.amnesty.or g/en/countries/europe-and-central-asia/kazakhstan/report-kazakhstan/

Bauer, H. M., Rodriguez, M. A., Quiroga, S. S., \& Flores-Ortiz, Y. G. (2000). Barriers to health care for abused Latina and Asian immigrant women. Journal of Health Care for the Poor and Underserved, 11(1), 33-44. https: //doi.org/10.1353/hpu.2010.0590

Cuffe, S. (2018, October 21). Honduran women find safety in numbers in migrant caravan. Aljazeera. Retrieved from https://www.aljazeera.com/news/2018/10/honduran-women-find -safety-numbers-migrant-caravan-181021185658508.html

Economic Commission for Latin America and the Carribean (ECLAC). (2018, December 10). Foreign ministers of El Salvador, Guatemala, Honduras and Mexico presented Comprehensive Development Plan in the framework of the Conference on the Global Compact for Migration [Press Release]. Retrieved from https://www.cepal.org/en/pressreleases/foreign-ministers-salvador -guatemala-honduras-and-mexico-presented-comprehensive

Ertürk, Y. (2006). Integration of the human rights of women and the gender perspective: Violence against women. United Nations Economic and Social Council (Vol. 70793). https://doi.org/10.1017/S0020818300006640

Joseph, J. (2017). Victims of femicide in Latin America: Legal and criminal justice responses. Temida, 20(1), 3-21. https://doi.org/10.2298/TEM17 01003J

Mejía Flores, S. (2006). Mujer indígena y violencia: Entre esencialismos y racismos. Revista México Indígena, 5.

OHCHR. (2018). ohchr | Committee on the Elimination of Discrimination against Women reviews report of Mexico. Retrieved from https://www.ohchr.org/EN/NewsEvents/ Pages/ DisplayNews.aspx?NewsID $=23344 \&$ LangID $=\mathrm{E}$

Olivera, M. (2006). Violencia femicida. Latin American Perspectives, 33(2), 104-114. https://doi.org/10.1177/0094582X05286092

The World Bank. (2018). Gender-based violence (Violence against women and girls). Retrieved from World Bank website: http://www.worldbank.org/ en/topic/socialdevelopment/brief/violence- against-women-and-girls

World Health Organisation (WHO). (2012). Understanding and addressing violence against women: Femicide. Retrieved from World Bank website: http://www.who.int/reproductivehealth/publications/violence /rhr_11_35/en/

World Health Organisation (WHO). (2017). Violence against women. Retrieved from World Bank website: http://www.who.int/news-room/f act-sheets/detail/violence-against-women 